日耳其 $106: 135-142,2003$

\begin{abstract}
安田京
松原第

王子 佳浯

二井 一則

新川 秀一
\end{abstract}

弘前大学医学部

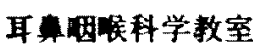

\section{降雪地帯におけるスギ花粉飛散状況とその予測 一弘前市における検討一}

キーワード: 子測、 スギ花枌我散、 スキ花枌症, 着化指数

はじめに

スキ花圽症はその患者数の多さから社会問题化してお

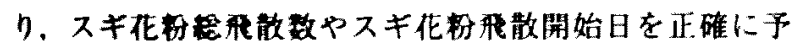
酎することが患者の QOL 向上といった㑡面からも重要

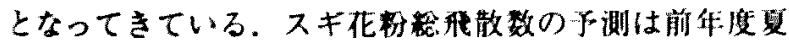
の気象条件による万陆 が般的であるが，近年，よ

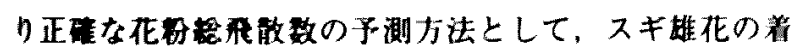

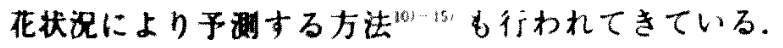
我々の㮱設では，1995年までは前年度夏の累皘段高気温 のデータをしとに化枌较秋散数の予測を行っていたが， この策件をもとにした予測は，年によっては大きく外れ ることがあり予测方法として不十分であった。そこで実 宗にスキ榯木の生態を反映するスキ雄花の着花状況を前 年度に钼察し数值化した着花指数を1996年より花枌総飛 散数の予测に採り入れてきた，今回，1996年から2002年 の弘前市におけるス丰花枌飛散状況を調查し，著化指数

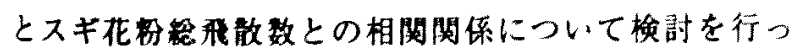
た。また，降雪地带の特改ともいえる飛散期の低温や降 雪なとの気象条件が花枌飛散にどのような影罳を及ほし ているのかを調查し，それをもとにした飛散開始日の予 既方法についても㛟討したので併せて報告する。
方法

1. 弘前市におけけるスキ花粉飛散状況

スギ花枌測定のために，弘前大学医学部の屋上にダー ラム型花枌捕集器を設谓し、ワセリンを㻎布したスライ ドガラスを24時間每に交换した，捕集された花粉をカル ベラ液で染色し， $1 \mathrm{~cm}^{2}$ あたりの花枌数を200倍の影橵鏡 下にカウントしその日の化枌数とした．1996年から2001 年までは 3 月 1 日よりスギ化物観測を開始し，2002年は 2月21日より钼测を開始した。初観測日は初めて1個/ $\mathrm{cm}^{2}$ 以上の化枌を钼測した日，我散開始日は連稳2 日以 上. 1 個 $/ \mathrm{cm}^{2}$ 以上観测した最初の日，我散終了日は 3 日 連繶して0 個 $/ \mathrm{cm}^{2} か ゙$ 楼いた坆初の日とした。

2. 前年度秋の着花指数とスキ正粉総飛散数との相関 着花指数は前年度の11月に弘前市内の特定されたスギ 林において屋外調查を行い，50本のスキ樹木を対象にし て, 雄花の着花状況を 6 段階（A：非常に多い，B：多 い，C：中等度，D：少ない， E：僅かにある， F：㧐 花が見えないで竍洒し，各本数に以下の係数を掛けた ものを合計して求めた。

着花指数 $=100 \mathrm{~A}+60 \mathrm{~B}+50 \mathrm{C}+40 \mathrm{D}+5 \mathrm{E}+0 \mathrm{~F}^{19}$

これにより得られた着花指数とスギ花枌総飛散数との相 関を单回淿分析により検封した。

3. 夏の気象条件と着花指数との相関 
表 1 弘前市におけるスギ花粉飛散状況

1996年から2002年におけるスギ花粉飛散状況を示す，初観测は例年 3 月初旬から中旬にみられ，3月中 旬から下旬に飛散が開始する。4月中旬に飛散のピークがあり，おおむね 5 月初旬に飛散は終丁する.

\begin{tabular}{|c|c|c|c|c|c|c|c|}
\hline & 1996 & 1997 & 1998 & 1999 & 2000 & 2001 & 2002 \\
\hline 初觀測日 & $3 / 14$ & $3 / 6$ & $3 / 6$ & $3 / 14$ & $3 / 4$ & $3 / 14$ & $2 / 28$ \\
\hline 我散開始日 & $3 / 26$ & $3 / 19$ & $3 / 13$ & $3 / 17$ & $3 / 23$ & $3 / 20$ & $3 / 10$ \\
\hline 熶高我散日 & $4 / 14$ & $4 / 8$ & $4 / 9$ & $4 / 17$ & $4 / 20$ & $4 / 10$ & $4 / 1$ \\
\hline 我散数（㑑/ $\mathrm{cm}^{2}$ ) & 70 & 151 & 279 & 84 & 512 & 250 & 94 \\
\hline 飛散終了日 & $5 / 4$ & $5 / 5$ & $4 / 25$ & $5 / 3$ & $5 / 20$ & $5 / 9$ & $4 / 24$ \\
\hline 㭲飛散数（個/cm'） & 480 & 904 & 1744 & 757 & 4923 & 1235 & 1219 \\
\hline
\end{tabular}

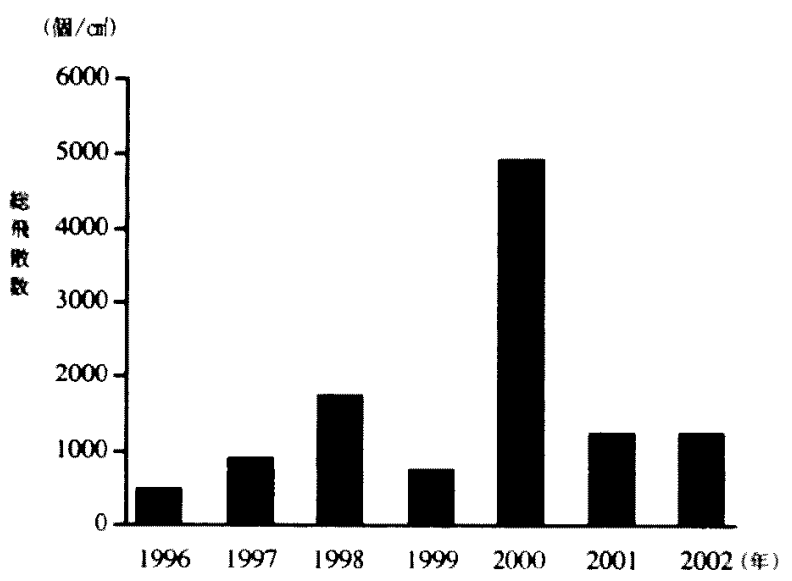

図 1 スギ花粉赭飛散数

1996年から2002年までの弘前市におけるスギ

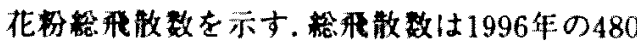
湖 $/ \mathrm{cm}^{2}$ が政も少なく，2000年の4923固 $/ \mathrm{cm}^{2}$ が取多かった。

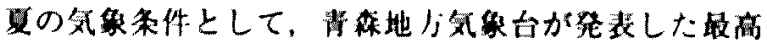

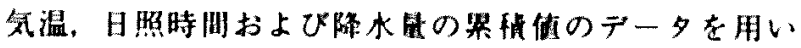
た。期間は週去 7 年間の5月1日から8月31日までと し，この期閒を10日こととに変えた部 1 力月阴の10タルー ブに区切り，10タルーフそれぞれの)期間について気象条 件と着花指数との相関を单回淿分析により检尉した。

4. 初観測日と我散開始日の予测

1月1日か・ら初钼测日および我散開始日までの日数と

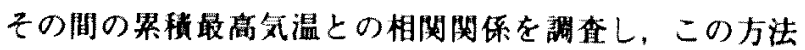
によって初観測日および飛散開始日の予測が可能である かを娭討した。

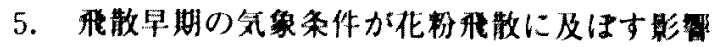

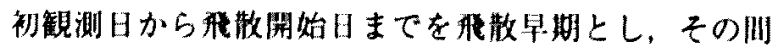
の日数と気鱼条件との閏俰から，我散早期の知象条件が 化枌飛散にどのような影整を及はすのかについて梌村し た、気象条件は初钼測日から散開始日までの累皘最高
気温と累程降雪田のデータを用いた。

\section{桔果}

1. 弘的市におけるスギ花㸮飛散状況

1996年から2002年にかけてのスギ花粉飛散状況を表1

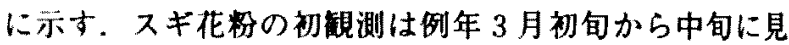
られ，3月中旬から下旬に飛散が開始するという結果で あったが，2002年は例年より花杨の飛散は早く，2月28 日に初穓測された。飛散開始日は2002年の3月10日が最 も早く，1996年の3月26日が最も遅かった４月中旬に 我散のビークがあり，1 日の最高飛散数は2000年 4 月20 日の512個 $/ \mathrm{cm}^{2}$ が取も多かった。おおむ标 5 月初旬に飛 敞は䅂了した（表 1)，スギ花物総飛散数は1996年の480 個 $/ \mathrm{cm}^{2}$ が蛜も少なく、2000年の4923個 $/ \mathrm{cm}^{2}$ が最当多か った（因 1).

2. 落花指数とスギ花粉総我散数上の相関

1996年から2001年にかけて測定したスギ雄花の着花指 数は145から1712であり，翌年のスキ花粉紷飛散数と有 意な正の相闺関係を示した，着花指数 $(\mathrm{X})$ と松飛散数 （Y）との関保は以下の一次式として表すことが可能で あった（図2).

$$
\begin{aligned}
& Y=2.624 \times X-132.793 \\
& (r=0.932, r=0.869, p<0.01)
\end{aligned}
$$

\section{3. 夏の気象条件と着花指数との相威}

5 月1日から8月31日まで, 計 1 力月間に区切った 10 グルーフそれぞれの期間について，気象条件と着花指数 との相成係数 $(\mathrm{r})$ および決定係数 $\left(\mathrm{r}^{2}\right)$ を表 2 に示した。

累程最高気温と着花指数は6月 1 日から6 月30日まで

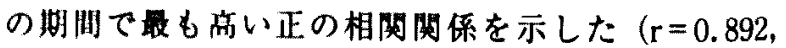
$r^{2}=0.796, p<0.05$ ）（图 $3 ）$ ．累皘日照時間と着花指数 についても，6月1日から6月30日までの期間で最も高 い正の相成阅俰を示した $\left(r=0.913, r^{2}=0.833\right.$, $p<0.05$ ）（図 4 ）。また，累䅪降水量と着花指数とは 6 


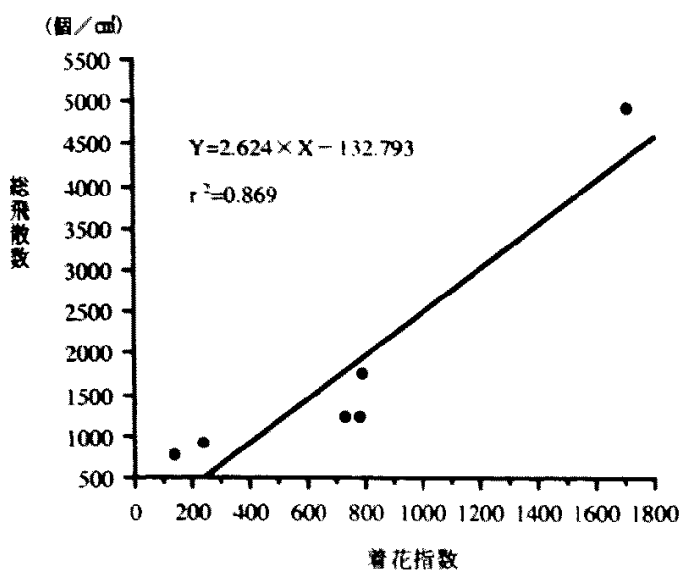

图 2 着花指数とスギ花枌松飛散数との相関 钝は当年の $1 \mathrm{~cm}^{2}$ 当たりのスキ花枌

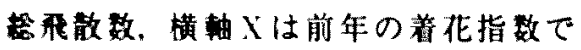

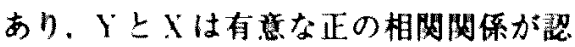
められた $(r=0.932, r=0.869, p<0.01)$. グラフは $Y=2.624 \times X-132.793$ の一次 回煌直線を示している。

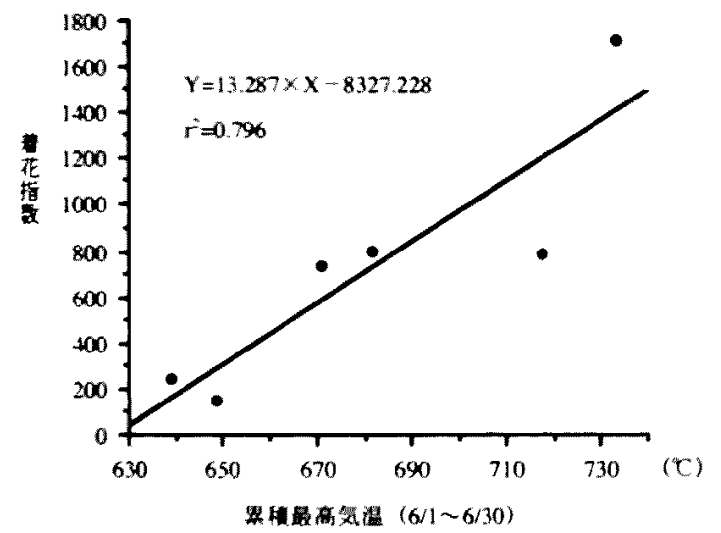

图3累最高気温と着花指数との相関

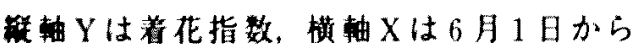
6月30日までの最高矣温の累皘值で，YとX は有意な正の相関関保が既められた $(r=0.892, r=0.796, p<0.05)$. クラフはY $=13.287 \times X-8327.228$ の一次回㛿直楾走示 している.

月11日から7月10日までの期間で最も高い負の相関関倸 を示した（r=-0.926, $r^{2}=0.857, p<0.01 ）$ (図 5).

\section{4. 初瀵測日および飛散開始日の予湘}

1996年から2002年にかけて1月1日から初観測日まで の日数は59日から74日であった。この期間の糸稍最高気 温は年によりばらつきがあり，2001年の $16.1{ }^{\circ} \mathrm{Cが}$ 樶も低 く，1997年の168. $3^{\circ} \mathrm{C}$ が最も高かった（表 3）。平均値は

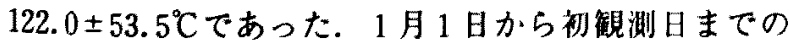

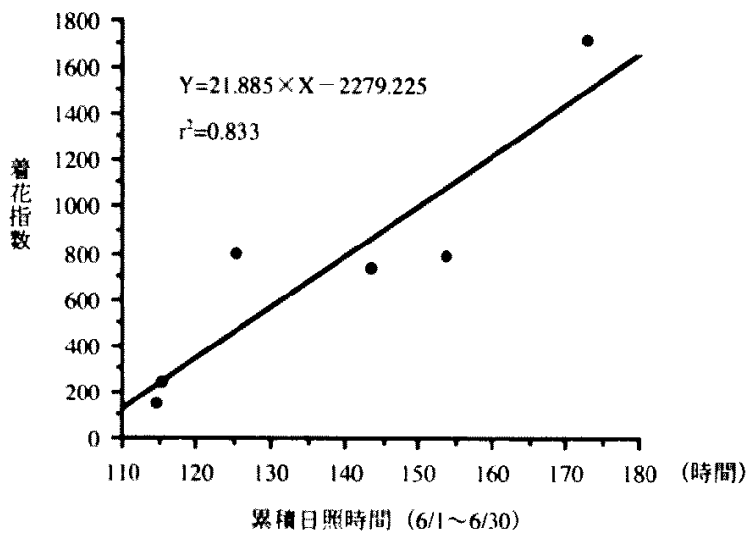

因 4 累皘日照時間と着花指数との相閲

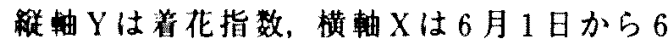
月30日までの日照時間の㹎皘值であり，YとX は正の相関闺倸が認められた $(r=0.913$, $\left.r^{r}=0.833, p<0.05\right) . タ ゙ ラ フ は ~ Y=21.885 \times X-$ 2279.225 の一次回㷌直線を示している.

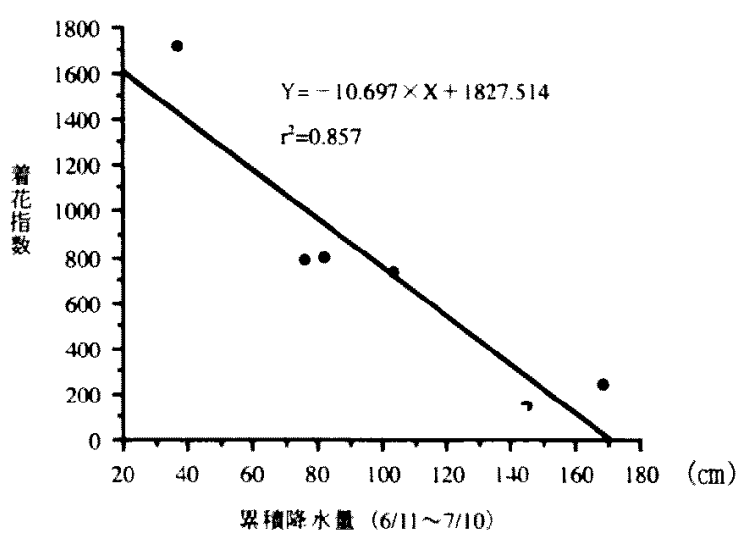

图 5 紫皘降水量之着花指数との相関

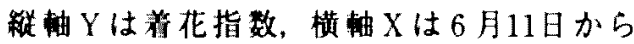
7 月10日までの降水量の累積值であり，Yと Xは负の相関関係が認められた $(r=-0.926, r=0.857, p<0.01)$.ダラフは $Y=-10.697 \times X+1827.514$ の一次回㷌直線 を示している.

日数と累皘最高気温との間に相関関係はなかった。 た，花粉総我散数との間にも相関関係はなかった。

一方，1996年から2002年にかけて1月1日から飛散開 始日までの日数は69日から86日であった（表4）。この

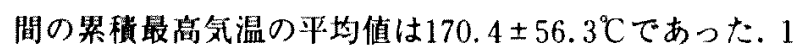
月 1 日から我散開始日までの日数と累程最高気温との間 に相関関係はなく，花粉総我散数との間にも相関関係は なかった。

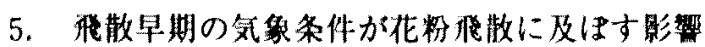
1996年から2002年に求ける初観测日から飛散開始日ま 
表 2 夏の気象条件と着花指数との相関

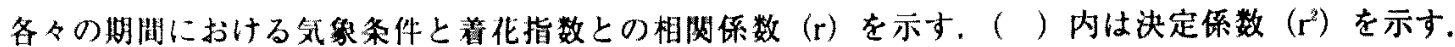

$(*: \mathrm{p}<0.05, * *: \mathrm{p}<0.01)$

\begin{tabular}{|c|c|c|c|c|c|c|}
\hline & \multicolumn{2}{|c|}{ 累皘湒高気温 } & \multicolumn{2}{|c|}{ 累皘日照㭙間 } & \multicolumn{2}{|c|}{ 累皘降水量 } \\
\hline & & $\left(r^{2}\right)$ & $r$ & $\left(r^{3}\right)$ & $\mathbf{r}$ & $\left(r^{2}\right)$ \\
\hline 5 月01日 -5 月 31 日 & 0.015 & $(0.0002)$ & 0.425 & $(0.181)$ & 0.068 & $(0.005)$ \\
\hline 5 月 $11 \mathrm{H} \sim 6$ 月 $10 \mathrm{H}$ & 0.128 & $(0.017)$ & 0.376 & $(0.141)$ & 0.249 & $(0.062)$ \\
\hline 5 月 21 日一 6 月 20 日 & 0.439 & $(0.193)$ & 0.605 & $(0.366)$ & 0.508 & $(0.258)$ \\
\hline 6 月 $01 \mathrm{H}-6$ 月 $30 \mathrm{H}$ & $0.892^{\circ}$ & $(0.796)$ & $0.913^{*}$ & $(0.833)$ & $-0.834^{*}$ & $(0.696)$ \\
\hline 6 月11日一 7 月 10 日 & 0.564 & $(0.318)$ & $0.880^{\circ}$ & $(0.774)$ & $-0.926^{* *}$ & $(0.857)$ \\
\hline 6 月 $21 \mathrm{H}-7$ 月 $20 \mathrm{H}$ & 0.305 & $(0.093)$ & 0.007 & $(0.0000)$ & 0.683 & $(0.466)$ \\
\hline 7 月01日 $\sim 7$ 月31日 & 0.410 & $(0.168)$ & 0.508 & $(0.258)$ & 0.700 & $(0.490)$ \\
\hline 7 月 $11 \mathrm{H} \sim 8$ 月 $10 \mathrm{H}$ & $0.816^{*}$ & $(0.667)$ & 0.769 & $(0.591)$ & $0.846^{*}$ & $(0.716)$ \\
\hline 7 月는 $\sim 8$ 月20日 & $0.832^{*}$ & $(0.692)$ & 0.791 & $(0.625)$ & 0.220 & $(0.049)$ \\
\hline 8 月01日 -8 月 31 日 & $0.822^{\circ}$ & $(0.675)$ & 0.610 & $(0.372)$ & 0.148 & $(0.022)$ \\
\hline
\end{tabular}

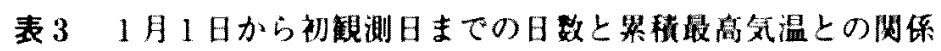

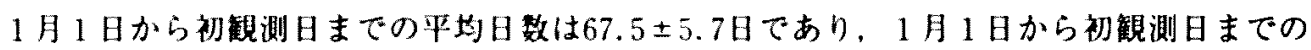

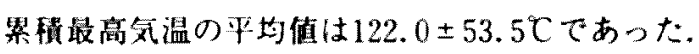

\begin{tabular}{|c|c|c|c|c|c|c|c|}
\hline & 1996 & 1997 & 1998 & 1999 & 2000 & 2001 & 2002 \\
\hline 初観湘日 & $3 / 14$ & $3 / 6$ & $3 / 6$ & $3 / 14$ & $3 / 4$ & $3 / 14$ & $2 / 28$ \\
\hline $\begin{array}{l}1 \text { 月 } 1 \text { 日からら初観湘日 } \\
\text { までの日数 }\end{array}$ & 74 & 65 & 65 & 73 & 64 & 73 & 59 \\
\hline 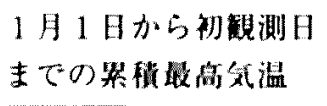 & 116.9 & 168.3 & 96.1 & 152 & 138.6 & 16.1 & 166.2 \\
\hline 綾化数数 & 480 & 904 & 1744 & 757 & 4923 & 1235 & 1219 \\
\hline
\end{tabular}

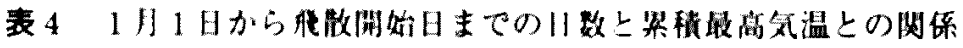

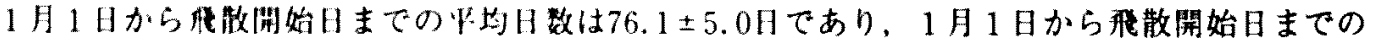

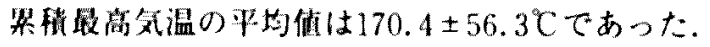

\begin{tabular}{|c|c|c|c|c|c|c|c|}
\hline & 1996 & 1997 & 1998 & 1999 & 2000 & 2001 & 2002 \\
\hline 俄散開始日 & $3 / 26$ & $3 / 19$ & $3 / 13$ & $3 / 17$ & $3 / 23$ & $3 / 20$ & $3 / 10$ \\
\hline $\begin{array}{l}1 \text { 月1日から升散開始 } \\
\text { 日までの日数 }\end{array}$ & 86 & 78 & 72 & 76 & 83 & 79 & 69 \\
\hline 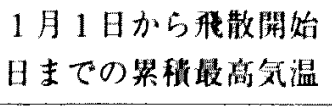 & 176.5 & 231.3 & 132.8 & 173 & 200.7 & 65.1 & 214 \\
\hline 䇥瓜散数 & 480 & 904 & 1744 & 757 & 4923 & 1235 & 1219 \\
\hline
\end{tabular}

での日数は，1999年の3日が报も智く，2000年の19日が

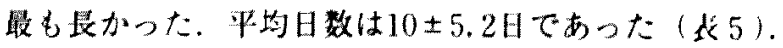

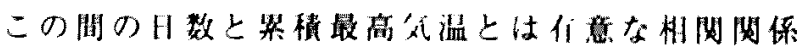

$(r=0.907, r=0.823, p<0.01)$ を示し，最高気温の 平均值とは有意な傊の相関関係 $(r=-0.900$, $\left.r^{\prime}=0.809, p<0.01\right)$ を示した。累税最高気温の平均值 
表 5 初観測日から我散開始日までの日数と気象条件（㹎皘最高気温，累皘降雪量）との関係 初観测日から飛散開始日までの平均日数は $10 \pm 5.2$ 日であった。この間の照稓最高気温の平均值は $50.2 \pm 15.9^{\circ} \mathrm{C}$ ，累積降雪量の平均值は $43.8 \pm 40.2 \mathrm{~cm}$ あった。

\begin{tabular}{|c|c|c|c|c|c|c|c|}
\hline & 1996 & 1997 & 1998 & 1999 & 2000 & 2001 & 2002 \\
\hline 初観測日 & $3 / 14$ & $3 / 6$ & $3 / 6$ & $3 / 14$ & $3 / 4$ & $3 / 14$ & $2 / 28$ \\
\hline 秉散開始日 & $3 / 26$ & $3 / 19$ & $3 / 13$ & $3 / 17$ & $3 / 23$ & $3 / 20$ & $3 / 10$ \\
\hline $\begin{array}{l}\text { 初银測日から飛散開始 } \\
\text { 日までの日数 }\end{array}$ & 12 & 13 & 7 & 3 & 19 & 6 & 10 \\
\hline 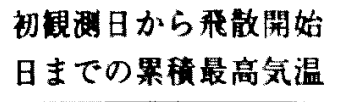 & 61.8 & 68.8 & 39.1 & 26.0 & 66.4 & 42.3 & 47.1 \\
\hline 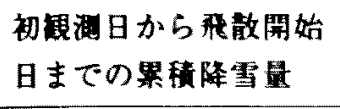 & 50 & 38 & 20 & 9 & 125 & 10 & 55 \\
\hline 紷瓜散数 & 480 & 904 & 1744 & 757 & 4923 & 1235 & 1219 \\
\hline
\end{tabular}

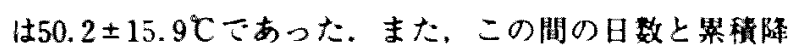
雪量とは有意な相成阅係 $(r=0.921 ， r=0.848$, $\mathrm{p}<0.01$ )を示し，粠程降雪量の平均值は $43.8 \pm 40.2 \mathrm{~cm}$ であった.

\section{考察}

近年，スキ花事整者は增加してきており，日本人の 的17.3\%がスキ花应に䍜照している上いわれてい

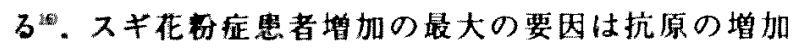
で、第2次世界大传の1950年 1960年代に植林された

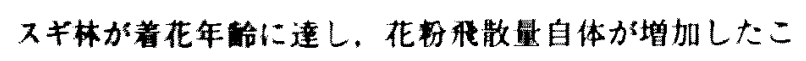

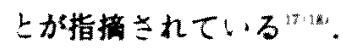

青累ではスキ人工林の面皘が秋田県，岩手県に次い で大きい上船告されている゙。1996年から2002年までの 弘前市におけるスキ花枌我散状况は，3月初旬から中句

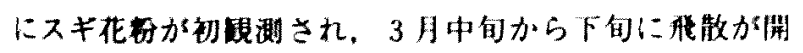
始し，5月前半に哌散は終了した。我散期间の平均值は 47.2土5.7日であった。，スキ化枌総我散数は少ない年で 480 倜 $/ \mathrm{cm}^{2}$ (1996年)，多い年では4923個 $/ \mathrm{cm}^{\prime}$ (2000年) であり，年次変功はあるものの総我散数の增加倾向は明

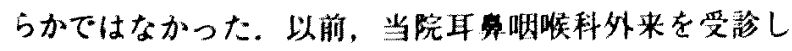
た患者を対像として行った調榃では，青禁の花材症の 主要抗原は，全国的にスキ化粉大我散となった1995年を 㔖機にそれまで最多であったイネ科花粉を上回り，その 後もスキ花㸮が最も多かっだ。したがって青森県にお いてもスキ花邪我散予測がスギ化㸮症患者の治撚や QOL向上に非常に重要な靖となってきている。

スギ花枌総飛散数に影䇾を及はす主な因子は，1）花 芽が分化し成長し始める前年の夏の気奥条件 ${ }^{1-12) ， 2 ） ~}$ 期木の生烈
考えられている，前年度夏の樶成気温，日照時間はスギ 花粉棇我散数と正の相阙にあり，湿度，降水量は負の相 関を示すとされている゙．しかし，花粉大飛散の翌年の 花粉は不作であり，たとえ前年の気象条件が良くても花

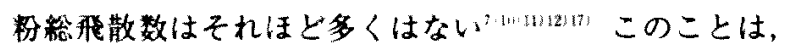
大量の着花によってスギ榯木の生理的な特性が変化する

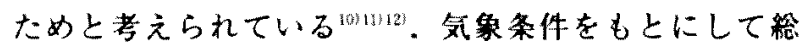
飛散数の予湘を行った場合には，こういった檄木の生態 を反映できず，年によって大きく予测值と異なる可能性 がある.最近では、総飛散数の子湘に雄花の着花状況を 観測する万法が採り入れられており、花粉総飛散数と高

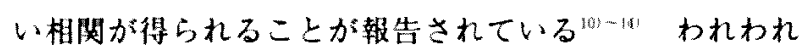
の結果でも，着化指数とスギ花物絰攸散数との間には有 意な正の相関阔係があり $p<0.01)$ ，着花指数を用いた方法はスギ花粉総飛散数 の予测に適していると考えられな。

前年度夏の気象条件と当年の花枌総我散数とは离い相 関関保を示すことが報告されているい'が，复の気象条 件と雄花の着花状況との関係は明らかではない，雄花の 着花状況が花㸮総飛散数上密接に関わるならば，夏の気 累条件か雄花の着花㧋況に与える影整を検討することに より，花粉総飛散数の甬测をより正碓に行うことが可能 である、そこで，专際に弘前甫において，どの時期の気 象条件が着花指数と相閣があるのかを調べるたかに，5 月1日から8月31日までの期閒を10日こととに変化させた 1 力月間で区切り，それぞれの期䦌における気象条件と

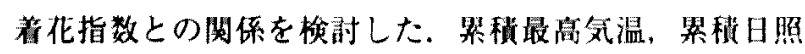

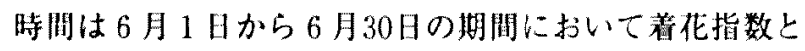
最も离い正の相闺にあり，紫㮴隆水量は6月11日から7 月10日の期間において有意な負の相威にあった。ま， 
累皘最高気温は 7 月中旬から8月の期間においても着花 指数と高い正の相関関係があった。この時期の弘前市に おける最高気温の平均值は $28^{\circ} \mathrm{C}$ から $29^{\circ} \mathrm{C}$ と高值であり， 最高気温が高いはど着花指数との相関は高かった。最高 気温と婎花の分化については，Taira ら"'が温度の異な ったインキュベーター内で雄花の分化を調査し， 24 Cで は雄花は全く分化せず，温度が高いほど雄花の分化は促 進されたと報告している，以上より，不ギ花枌総飛散数 の子湘は前年度の着花指数を用いて子測が可能であり， 弘前市における婎花の着花状況は6月の気象条件に湒も 影整されることが示唆された。 また，7月中旬から8月 の最高気温も婎花の分化を促進していると考元られた。 しかし，着花指数を用いた予测方法でも化杨源の同定の 問題や着花状況の钼察方法などの間题点があり ${ }^{(2)}$ これ らの問题点を解決しながら今後さらに洞植を継してい く必要があると思われた。

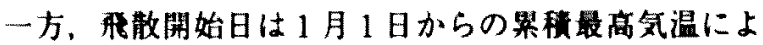
る力法"いよって予测が可能であるが，スキの生理的 な条件を考虑し，スギ雄花の休眠打破日を推定し子测す る方法"なども報告されている。しかし，弘前市におい て1月1日から初親测日および飛散開始日までの棵稍最 高気温は，1997年ではそれぞれ，168.3C，231.3 Cと高 值であったが, 2001年では16.1 C.65.1Cと著明に低く。 年により滑たりが大きかった１月1日から初段測日お よび我散開始日までの日数とその間の累穔最高気温との 間に相関関保仕なかった。たがって、この方法に上る 初钼測日や我散開始日の予測は弘前市においては不道切
であることが明らかになった，休眠打破日についても检 討したが，現時点では满足のいく結果は得られなかった。

青森県では 3 月，4月に入っても降雪があり，飛散期 の気象条件が花枌飛散に及はす影部が大きいと考えられ る。初钼湘日から飛散開始日までの日数は，最も短かっ た年は 3日(1999年)，最も長かった年は19日(2000年)， 平均日数は $10 \pm 5.2$ 日であり全国平均 $\left(22 \pm 6\right.$ 日 ${ }^{23)}$ と比 べて短かった．1999年のように，初钼測後 $10^{\circ}$ C以上の暖 かい日が㿠き，間隔をあけず飛散が始まる年もある （因 6)．また，2000年のように，初钼湘後に急に気温が 下がり降雪が続き，飛散開始が遅れる年もある(图7)。 初钼測日から飛散開始日までの日数とこの間の累皘最高 気温とは有意な相妣 $\left(r=0.907, r^{2}=0.823, p<0.01\right)$ があり，曼氛温の平均值との間には有意な負の相関 $\left(r=-0.900, r^{2}=0.809, p<0.01\right)$ があった。また，

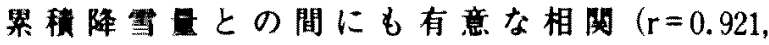

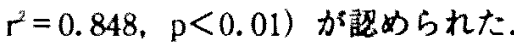

すなわち，我散早期における最高気温が高ければ高い ほと，そして降雪年が少なければ少ないほど，初钼測日 から升散開始日までの期間は短くなる。逆に最高気温が 低く，降雪が多い年は初钼测日から飛散開始日までの期 間は長くなるということが示唆される。初観測日から飛

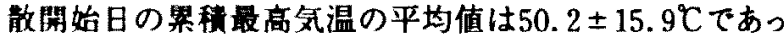
た.したがって，スギ花物の初観測後に日々の最高気温

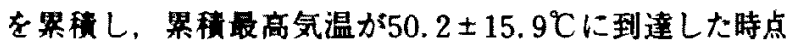
で我散が開始されることが予湘される。またここの間の

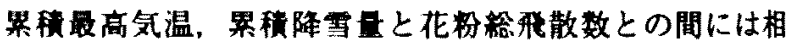

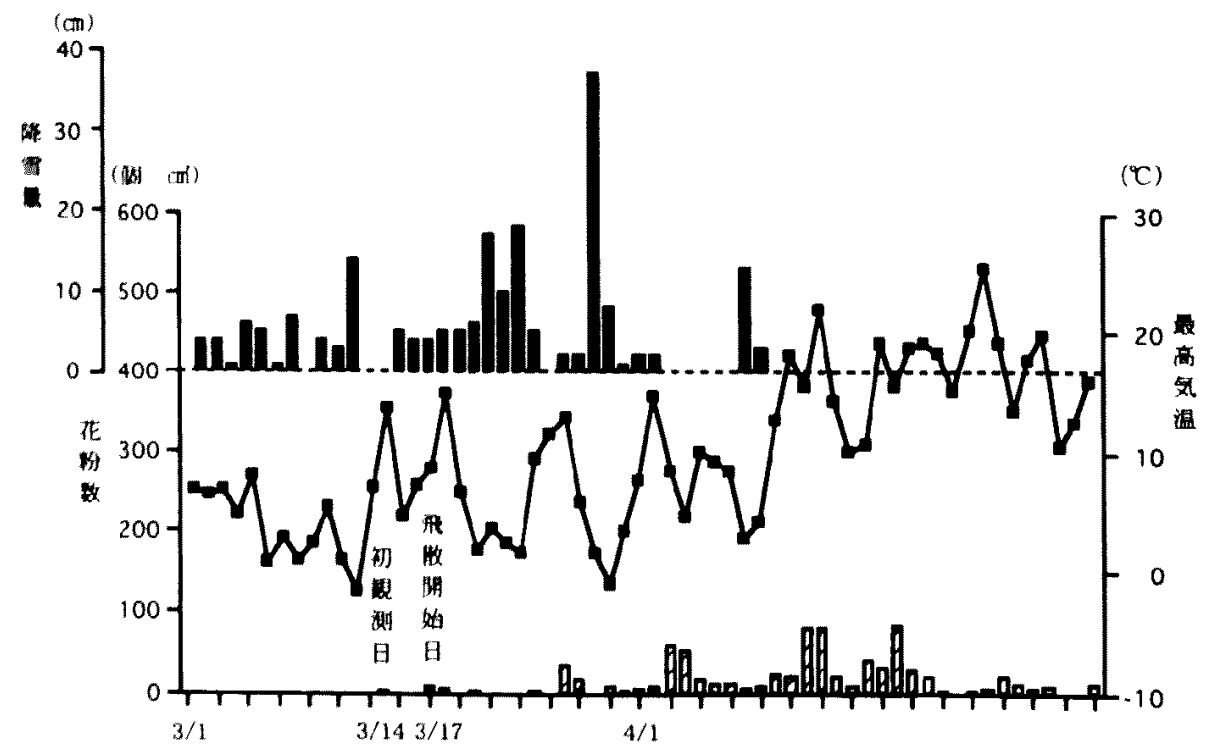

园6 ス丰花㸮开散と飛散期の気象条件との関係（1999年）

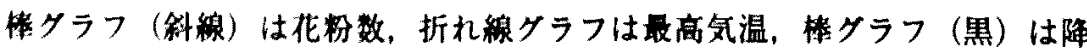

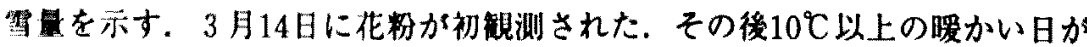
釈き，3月17日に我散開始となった，総飛散数は757個 $/ \mathrm{cm}^{2}$ と少なかった。 


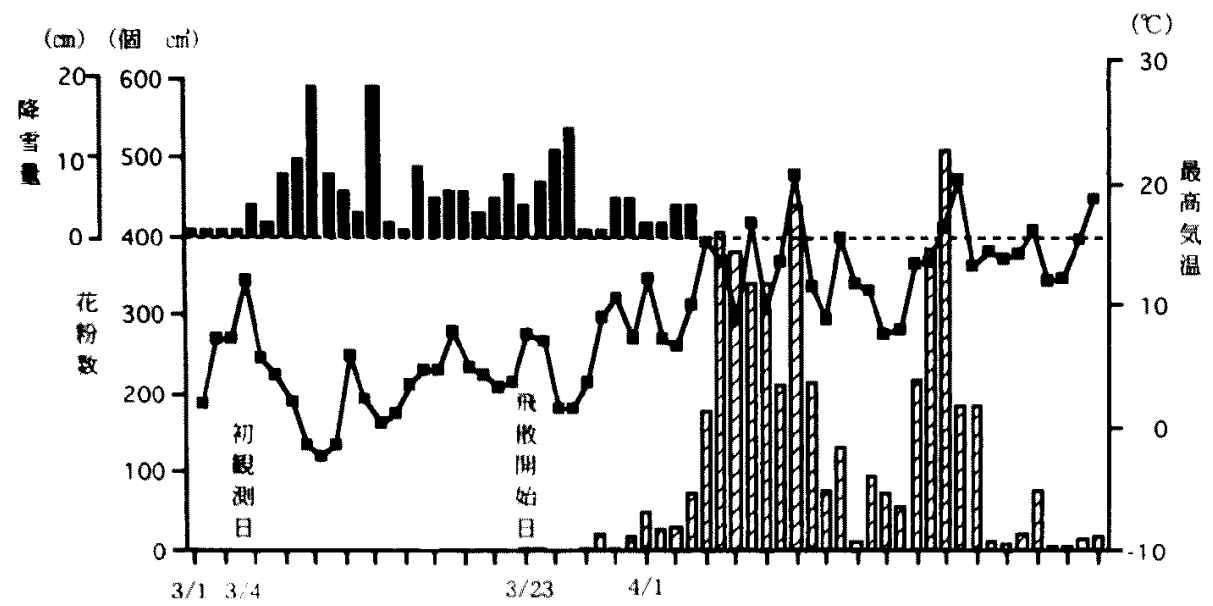

因 7 スギ花枌我散と飛散期の弎象条件との関係（2000年）

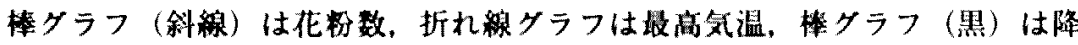

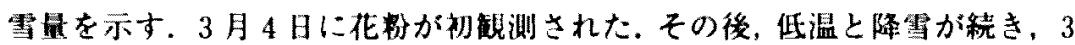
月23日に飛散開始となった。稔飛散数は4923周 $/ \mathrm{cm}^{2}$ と多かった。

関成はなかったことより，我散早期の気象条件はシー スン全体としての花枌校飛散数には大きく影整せず，初

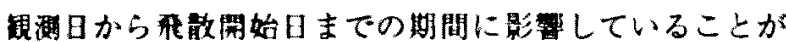
示酦された。

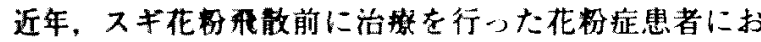
いて，シースン中の症扰轻娍が証明され，スギ花㸮症の

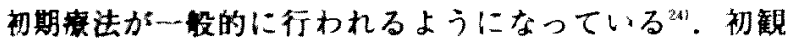
目表されるように，我散開始日以前にもスギ花粉我

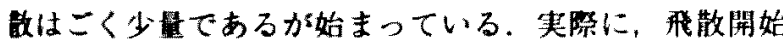

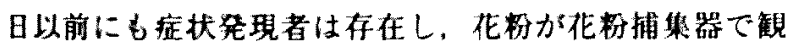
成されない少量であっても抗原が綵り返し負荷当れるこ とによって，楀粘限の過制性が徐々に九進し，感受性が 必要抗原星と合致した時点で死状発晛に至ると考えられ ている゙ここで，治猠をいつ開始するかが間题となる が、弘前市の上うに初镜测日から㧴散開始日までの期间

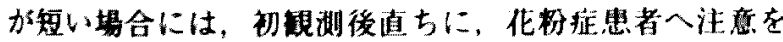
呼ひか忛，少しでも早く治㜔を開始する必要があると考 えられた。馬場战はスキ花枌症患者を抗原に对する感受 生の遧いによって高感受性群と低感受性群に分け，高感 受性群では症状発現の初期または花㸮我散の初期に治療 を開始するという初期法が非常に重要となると述べて いる，降雪地带では飛散開始日を正確に予測することは 虽しいとされるが，弘前市においては，まず初観測日を 起点上し，そこから飛散開始日を予测することがスキ化

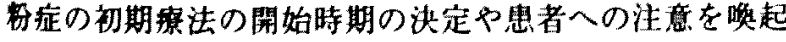
するのに有用であると考えられた。

\section{考支献}

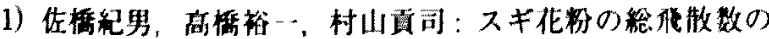

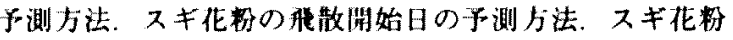
のすべて.メデル・ジャーナル社 1995: 63-75

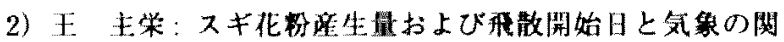
保. JOHNS 1988: $4: 185-190$

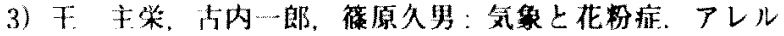
ギーの臨床 $1984 ； 4: 537-540$.

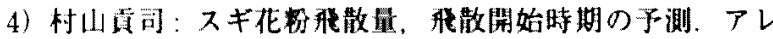
ルギー科 $1996 ; 1: 264-270$.

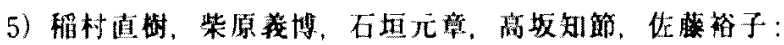
スギ花枌飛散に与方る気像の影雪。日耳累 $1988 ; 91$ 907-914.

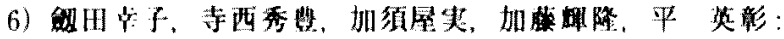

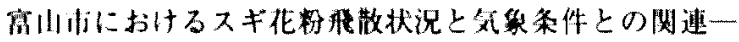

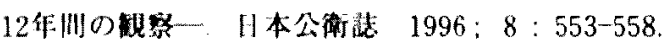

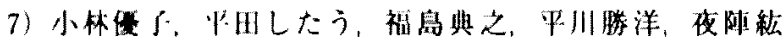

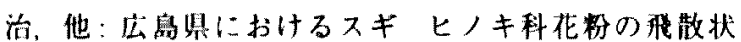
況. 耳复 $1997 ; 43: 818-824$.

8) Teranishi H, Kenda $Y$, Katoh T, Kasuya M, Oura E, et al : Possible role of climate change in the pollen scatter of Japanese cedar Cryptomeria japonica in Japan. Clim Res $2000 ; 14: 65-70$.

9）佐竹充章，柴原博，石垣元章，高圾知節：仙台地方に

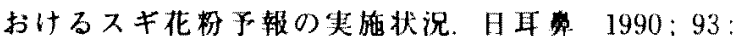
171-176.

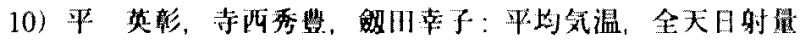
及び着化指数を用いたスギ空中化枌総化敬数の予测方法

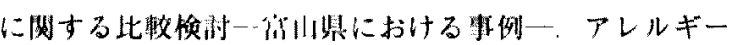
$1997: 46: 489-495$.

11) Taira $H$, Teranishi $H$, Kenda $Y$ : The formation of pollen in male flowers and yearly atmospheric pollen counts of 
Cryptomeria japonica in the following year. Allergol Int $1998: 47: 297-30^{2}$

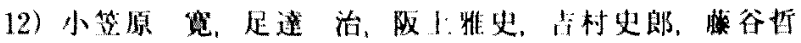

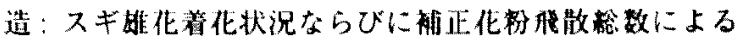

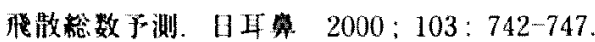

13) Taira $H$, Teranishi $H$, Kenda $Y$ : Male flowering index can predict the annual airborne pollen count of Cryptomeria japonica at different altitudes. Allergol Int $2000 ; 49: 175-181$.

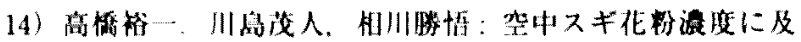

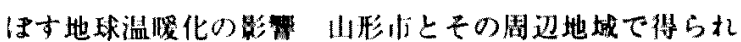
た予测耗果一、アレルキー 1996：45:1270-1276.

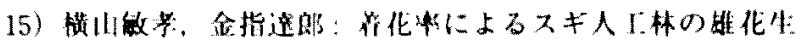

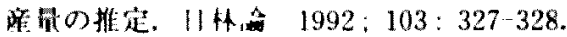

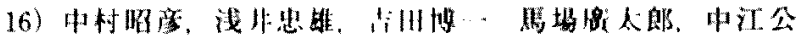

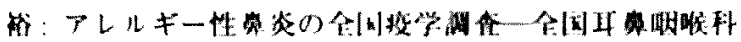

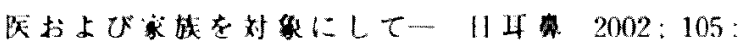
$215-224$.

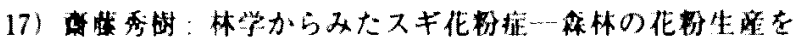

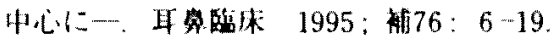

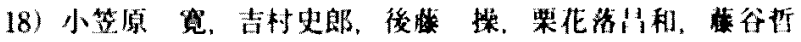

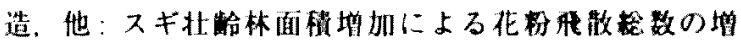
加. 化物战 $1998 ; 44: 97-105$.

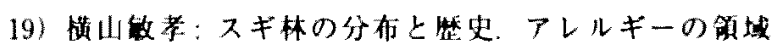
$1994: 1: 159-163$
20）间烟滜子，安田 今，二弗一則，松原 第：弘前大学耳

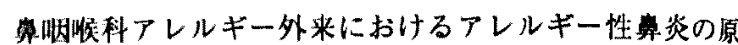

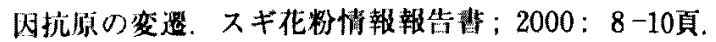

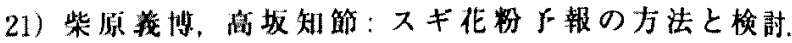
JOHNS $1988 ; 4: 191-195$.

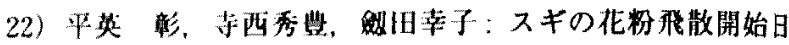
のケ测について一植物生理の锶点から一。アレルギー $1992 ; 41: 8692$.

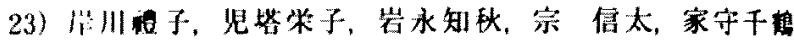
子、他：わが国の空中スキヒと科花粉長期調查一

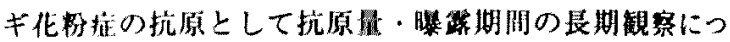
いて一. アレルキー 2001:50:369-378.

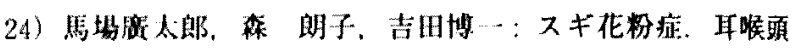
培 $1995 ; 67: 230-239$.

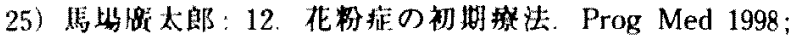
18:2814:3817

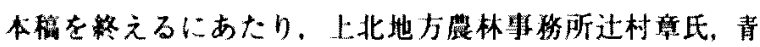

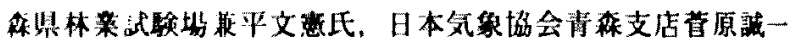

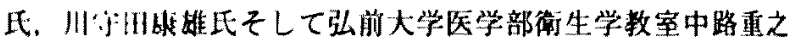

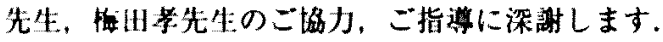

(2002年8月8日受稳 2002年10月4日受理)

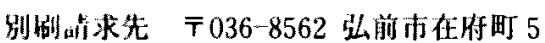

弘间大学医学部耳鼻咽喉科学教室 安田 京

Prediction of Japanese Cedar Pollen Emission in a Snowy Area -Surveillance in Hirosaki City-

Kyo Yasuda, MID., Atsushi Matsubara, M.D., Kasumi Oji, M.D.

Kazunori I:ulai, .1.D, and Hideichi Shinkawa, M.D.

In partment of () Mlaryngology. Hirosaki I niversity School of Medicine, Hirosaki

\begin{abstract}
Japame werdar is the most common pollinosis allergen in Japan. Predictions of total pollen counts and the first 2 or more days of the Japanese cedar pollen season ar. beneficial to patients. We developed predictive methods for those 2 factors in Hirosiki.

Wr. conducted an atmospheric Japanese cudar pollen survey from 1996 to 2002 in Hirosaki and compared yearly data with the male flowering index counted in 50 cedar trees in the preceding autumn. The male flowering index correlated highly pesitively with total cedar pollen counts in regression analysis, indicating its usefulness in predicting total pollen counts. Although the number of days from January 1 to the first day of continuous pollen emission showed no correlation with the cumulative maximum temperature during these days, the number of days from the day of first detection of pollen emission (minimum of 1 particle per sq. $\mathrm{cm}$ ) to the first day of continuous pollen emission correlated highly with the cumulative maximum temperature and cumulative amount of snowfall on these days, suggesting that it is possible to predict the firs day of continuous pollen rmiscion by the cumulated daily maximum temperature after the day of first detection of pollen emission.
\end{abstract}

Keywords: prediction, pollen emission, Japitllese cedar, pollinosis, male flowering index 